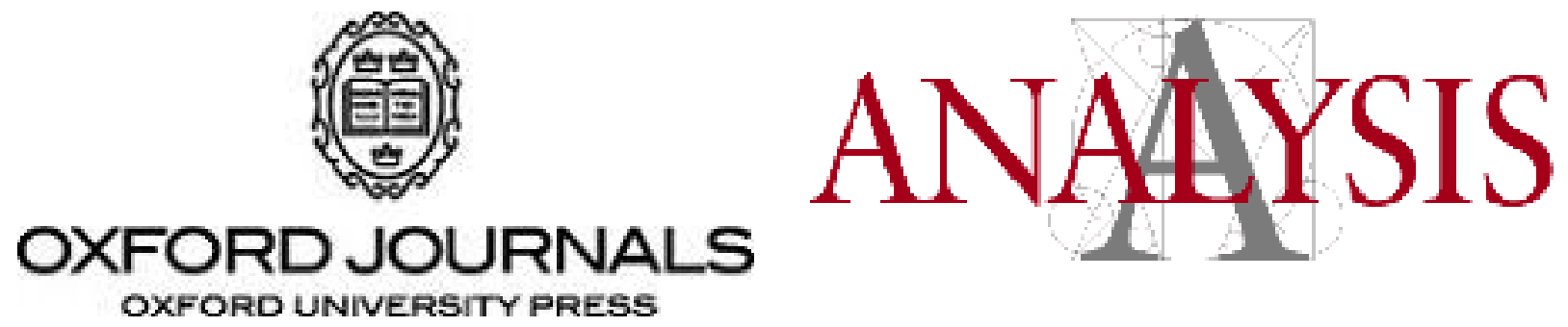

\author{
Paradox without Self-Reference \\ Author(s): Stephen Yablo \\ Source: Analysis, Vol. 53, No. 4 (Oct., 1993), pp. 251-252 \\ Published by: Oxford University Press on behalf of The Analysis Committee \\ Stable URL: http://www.jstor.org/stable/3328245 \\ Accessed: 17/01/2010 19:54
}

Your use of the JSTOR archive indicates your acceptance of JSTOR's Terms and Conditions of Use, available at http://www.jstor.org/page/info/about/policies/terms.jsp. JSTOR's Terms and Conditions of Use provides, in part, that unless you have obtained prior permission, you may not download an entire issue of a journal or multiple copies of articles, and you may use content in the JSTOR archive only for your personal, non-commercial use.

Please contact the publisher regarding any further use of this work. Publisher contact information may be obtained at http://www.jstor.org/action/showPublisher?publisherCode=oup.

Each copy of any part of a JSTOR transmission must contain the same copyright notice that appears on the screen or printed page of such transmission.

JSTOR is a not-for-profit service that helps scholars, researchers, and students discover, use, and build upon a wide range of content in a trusted digital archive. We use information technology and tools to increase productivity and facilitate new forms of scholarship. For more information about JSTOR, please contact support@jstor.org.

Oxford University Press and The Analysis Committee are collaborating with JSTOR to digitize, preserve and extend access to Analysis. 
there are no chairs, but he should see himself as correcting a metaphysical error embodied in vulgar usage. What moral should be drawn about other attempts that have been made to reconcile apparently revolutionary metaphysical theories with ordinary language is a topic that I must leave for discussion on another occasion. ${ }^{9}$

\author{
New College \\ Oxford OX1 3BN \\ mackie@vax.oxford.ac.uk
}

${ }^{9}$ I am grateful to several people at Oxford with whom I discussed an early version of this paper (especially Robert Frazier, who also commented on a later draft) and to Joan Mackie for comments on the penultimate draft. Some material in $\$ \$ 1$ and 2 is reproduced, with permission from Blackwell Publishers, from my Critical Notice of van Inwagen, Material Beings, Philosophical Books 34 (1993) 75-83.

\title{
Paradox without Self-Reference
}

\section{STEPHEN YABLo}

Why are some sentences paradoxical while others are not? Since Russell the universal answer has been: circularity, and more especially self-reference. ${ }^{1}$

Not that self-reference suffices for paradox. Such a view is refuted by the work of Gödel and Tarski, and by various commonsense examples, such as 'For the last time, stop that racket!' and 'So dear Lord to Thee we raise, this our hymn of grateful praise'. What many do seem to think is that some sort of self-reference, be it direct or mediated, is necessary for paradox. So one often hears that the surest way of keeping a language paradox-free is to impose an absolute ban on all self-reference. 'This may be using a cannon against a fly,' it is said, 'but at least it stops the fly.'

Except that it does not stop the fly: paradoxes like the Liar are possible in the complete absence of self-reference. Imagine an infinite sequence of sentences $S_{1}$, $S_{2}, S_{3}, \ldots$, each to the effect that every subsequent sentence is untrue:

$\left(\mathrm{S}_{1}\right)$ for all $k>1, \mathrm{~S}_{k}$ is untrue,

$\left(\mathrm{S}_{2}\right)$ for all $k>2, \mathrm{~S}_{k}$ is untrue,

$\left(S_{3}\right)$ for all $k>3, S_{k}$ is untrue, ...

${ }^{1}$ Some semantical paradoxes, for instance Grelling's, trade not on self-reference but on circularity of other kinds. Self-reference has seemed essential to Liar-like paradox, however. This note gives an example of a Liar-like paradox that is not in any way circular. 


\section{STEPHEN YABLO: ROY SORENSEN}

Suppose for contradiction that some $S_{n}$ is true. Given what $S_{n}$ says, for all $k>n, S_{k}$ is untrue. Therefore (a) $\mathrm{S}_{n+1}$ is untrue, and (b) for all $k>n+1, S_{k}$ is untrue. By (b), what $S_{n+1}$ says is in fact the case, whence contrary to (a) $S_{n+1}$ is true! So every sentence $S_{n}$ in the sequence is untrue. But then the sentences subsequent to any given $S_{n}$ are all untrue, whence $S_{n}$ is true after all! I conclude that self-reference is neither necessary nor sufficient for Liarlike paradox.

University of Michigan

Ann Arbor, MI 48109-1003, USA

syablo@um.cc.umich.edu

\section{The Earliest Unexpected Class Inspection}

\section{Roy A. SORENSEN}

\section{Memo: From the Chairman to new faculty}

Now that you have settled into your new post, I am required to evaluate your teaching performance. The semester is well under way, so the sooner this is done, the better. If we were being scientific about sampling your teaching, the class observation would be a surprise inspection. Thus reason dictates that the visit should occur on the first day that you do not believe it will occur. But on reflection, this is an impossible demand. Could I give the inspection next Monday? No, because you would realize that Monday is the first available unexpected day. What about the next class on Tuesday? Well the previous elimination would make Tuesday the first available unexpected day. Hence, it falls prey to the previous reasoning. And indeed, parallel reasoning would eliminate all of the remaining days. Hence, the earliest unexpected inspection is impossible. Since we hired you in a buyer's market, you have obviously noted the resemblance to the surprise examination paradox. But you may have not noticed that the elimination proceeds in the reverse direction. It is odd that such a reversal could be effected by substituting a definite description ('The event will occur on the first unexpected day') for an existential generalization ('The event will occur on an unexpected day'). But that's logic for you. Thus I am compelled to take refuge in philosophy department's custom of asking you to propose a day for the class visit.

503 Main Building, Washington Square East New York University, New York, NY 10003, USA sorensen@acfcluster.nyu.edu 